ISSN:2528-9527

E-ISSN: 2528-9535

Yıl Year: 11

Cilt Volume: 18

Sayı Issue: 39

Temmuz July 2021

Makalenin Gelis Tarihi Received Date: 16/12/2020

Makalenin Kabul Tarihi Accepted Date: 17/02/2021

\title{
Sosyal Girişimcilik ile Sosyal Hizmet Arasındaki İlişkinin Değerlendirilmesi
}

\author{
DOI: $10.26466 /$ opus.841939
}

$*$

\section{Enes Apaydın ${ }^{*}$ Fatih Altun **}

* Yl. Öğr., Bandırma Onyedi Eylül Üniversitesi Sağlık Bilimleri Enstitüsü, Balıkesir/Türkiye E-Posta: enes.apaydinn@gmail.com

ORCID: 0000-0002-7026-6627

** Dr. Öğr. Üyesi, Bandırma Onyedi Eylül Üniversitesi, Sağlık Hizmetleri MYO, Balıkesir/Türkiye E-Posta: fatihaltun75@gmail.com

ORCID: $\underline{0000-0001-5464-0909}$

Öz

Sosyal girişimcilik en temel anlamıyla toplumda var olan sorunlar karşısında girişimcilik bakış açısıyla çözümler oluşturmak şeklinde görülmektedir. Sosyal sorunlar karşısında hak temelli yaklaşımla çözümler üreten sosyal hizmet meslek ve disipliniyle son dönemlerde bilinirliği artan sosyal girişimcilik kavramı arasında belirgin ortak noktalar söz konusudur. Hem sosyal hizmet uygulamaları hem de sosyal girişimler insani değerler çerçevesinde, sosyal sorunlar karşısında yaratıcı ve yenilikçi çözümler üreterek toplumun kalkınmasına, değişimine destek olmaktadır. Bireylerin topluma aktif olarak katılımını sağlayarak sosyal işlevselliklerinin iyileştirilmesine yardımo olan sosyal girişimler, sosyal refah politikasının bir parçası haline gelmiştir. Bu çalışmanın amacı literatürden ve saha uygulamalarından hareketle, sosyal değişim ve gelişme açısından günümüzde önemli bir konumda olan sosyal girişimcilik kavramının sosyal hizmet meslek ve disipliniyle birlikte incelemektir. Bu amaca ulaşabilmek için öncelikle girişimcilik, sosyal girişimcilik ve sosyal hizmet kavramlarn incelenmiştir. Daha sonra sosyal girişimcilerin ve sosyal çalışmacılarm sahip oldukları ortak roller ve değerler irdelenmiştir. Son olarak bu iki alan arasındaki ilişkinin uygulamaya yansımalarına yönelik tespitlere yer verilerek çalışma tamamlanmıştır.

Anahtar Kelimeler: Sosyal girişimcilik, sosyal hizmet, toplum kalkınması. 
ISSN:2528-9527

E-ISSN: 2528-9535

Yıl Year: 11

Cilt Volume: 18

Sayı Issue: 39

Uluslararası Toplum Araştırmaları Dergisi

International Journal of Society Researches

Temmuz July 2021

Makalenin Gelis Tarihi Received Date: 16/12/2020

Makalenin Kabul Tarihi Accepted Date: 17/02/2021

\title{
Evaluating the Relationship Between Social Entrepreneurship and Social Work
}

*

\begin{abstract}
Social entrepreneurship is defined as creating solutions from the perspective of entrepreneurship in the face of existing problems in the society. There are certain common points between the social work profession and discipline, which produces solutions with a rights-based approach to social problems, and the concept of social entrepreneurship, whose awareness has increased recently. Both social work practices and social initiatives support the development and change of society by producing creative and innovative solutions against social problems within the framework of human values. Social initiatives that help improve social functionality by enabling individuals to participate actively in society have become a part of social welfare policy. The aim of this study is to examine the relationship between the concept of social entrepreneurship, which is an important position in terms of social change and development, and social work profession and discipline. To achieve this goal, the concepts of entrepreneurship, social entrepreneurship, and social work have been examined first. Then, the common roles and values of social entrepreneurs and social workers are examined. Finally, the study was completed by including the reflections of the relationship between these two areas on the application.
\end{abstract}

Keywords: Social entrepreneurship, social work profession, social welfare. 


\section{Giriş}

Küreselleşmeyle birlikte birçok alanda hızlı değişim ve dönüşümler yaşanmıştır. Özellikle ulaştırma ve iletişim alanlarında yaşanan değişimler dünya pazarları arasındaki sınırları aşındırmıştır. Dünya pazarları daha kolay ulaşabilir bir hal almış olup bu durum girişimciler açısından yeni birçok fırsatın doğmasını sağlamıştır. Bu fırsatların en önemlilerinden biri, girişimcilerin dünyanın her tarafına ulaşabileceği bir düzende mevcut işletmelerinin sınırlarının genişlemesi olmuştur. Bilgi teknolojilerinde yaşanan gelişmelere paralel olarak da girişimciler toplum hakkında daha geniş ve hızlı bilgilere ulaşmaya başlamıştır. Elde ettikleri bu bilgileri topluma değer katacak ürün ve hizmetlerin üretiminde kullanarak girişimsel faaliyetlerini artırmışlardır. Diğer taraftan küreselleşmenin ve bilgi teknolojisinin hızla gelişmesi, malların, sermayenin ve insanların serbest dolaşımını arttırmış böylece küresel rekabetin artmasına neden olmuştur. Küresel ekonomik rekabetin etkisi toplumda giderek daha fazla kendini göstermeye başlamıştır. Böyle bir ortamda var olan girişimciler de ayakta kalabilmek için mevcut düzene uyum sağlama stratejisine gitmişlerdir. Bu stratejinin temel odağını yenilikçilik kavramı oluşturmaktadır (Ağca ve Yumuşakipek, 2015).

Küreselleşmenin toplumda yol açtığı olumsuz etkiler karşısında üretme potansiyelini artıran girişimciler, girişimcilik konusunda yeni çalışma alanları oluşturmaya başlamışlardır. Bu yeni alanlardan biri şüphesiz sosyal girişimciliktir. Sosyal girişimcilik uygulamaları, özellikle 2000'li yılların başlarında bir ivme kazanıp toplumda giderek yaygınlığını artırmasına rağmen girişimcilik faaliyetlerinden farklı bir hareket planı çizerek elde ettikleri kârı sermayeye aktarmak yerine bu kârı sosyal faydaya katkı sağlayacak şekilde kullanmışlardır (Işık, 2015). Bu durum sosyal girişimciliğin kavramsal çerçevesine de yansımıştır. Girişimcilik kelimesinin başına sosyal kelimesinin getirilmesi girişimciliği çok farklı bir boyuta taşıyarak sosyal hayatın bütün alanına taşımaktadır (Martin and Osberg, 2007). Sosyal hayatta mevcut bütün sorunlara müdahale eden sosyal hizmet meslek elemanları gibi sosyal girişimciler de toplumsal dönüşümün bir değişim aracıdır. Sosyal girişimler, toplumsal sorunlar karşısında maddi bir kâr ve faydayı ön planda tutmadan sorunları çözmeye odaklanır ve sorunların bir daha yaşanmaması için 
stratejiler geliştirirler. Bu noktada tıpkı bir ticari girişimci gibi davranarak başkalarının göremediğini görüp yeni fırsat ve olanaklar yaratırlar. Sorunlar karşısında uygulanan sistemlerde değişime giderler ve yeni yaklaşımlar bularak insan hakları perspektifinde yeni çözüm kapıları açarlar (Meydanoğlu, 2018).

Sosyal girişimcilerin sayılan özelliklerine bakıldığında sosyal hizmet ile birçok yönüyle bağlantılı olduğunu görülmektedir. Sosyal hizmet alanının dünyada önemli bir konumda olan iki kuruluşunun sosyal hizmete getirdiği tanımlara bakıldığında, sosyal girişimciliğin bazı önemli işlevlerinin sosyal hizmetin kabul görmüş tanımlarında olduğu fark edilmektedir. Bu tanımlardan birini yapan Uluslararası Sosyal Hizmet Uzmanları Federasyonu (IFSW)'e göre "Sosyal hizmet; sosyal değişimi ve gelişimi, sosyal bütünleşmeyi, insanlarn güçlendirilmesini ve özgürleşmelerini destekleyen uygulama temelli bir meslek ve akademik disiplindir. Sosyal hizmet, sosyal adalet, insan hakları, ortak sorumluluk ve farklılılara sayg ilkelerini merkeze alır. Sosyal hizmet teorileri, beşeri bilimler, sosyal bilimler ve yerel bilgi ile desteklenen sosyal hizmet, yaşam zorluklarıla mücadele etmek ve iyilik halini geliştirmek için insanlarla ve yapılarla çalışır. Sosyal hizmetin bu tanımı ulusal ve/veya bölgesel düzeylerde geliştirilebilir" (Truell, 2014). Bir diğer önemli tanımı yapan Uluslararası Sosyal Hizmet Okulları Birliği (IASSW)'e göre sosyal hizmet: "Toplumsal iyilik halini artırmak amacıyla sosyal değiş̧ime, insan ilişkilerinde sorun çözmeye, güçlenmeye ve özgürleşmeye katkı sağlayan bir meslektir. Sosyal hizmet, insan davranışı ve sosyal sistem teorilerini kullanarak insanların çevreleriyle etkileşime girdikleri noktalara müdahale eder. Sosyal hizmet disiplini için insan haklarn ve sosyal adalet ilkeleri temel önemdedir" (Thompsan, 2014).

Bu tanımlardan yola çıkılarak sosyal girişimciliğin ve sosyal hizmetin benzer araçlar ve stratejiler kullanarak sorunlar karşısında çözüm odaklı hareket ettiklerini, insanların sosyal işlevselliklerini artırmak için kâr amacı gütmediklerini, insanları güçlendirmeye çalıştıklarını ve bu doğrultuda toplumsal değişim ve dönüşüme katkı sağladıkları görülmektedir. Bu çalışmada sosyal hizmet meslek ve disiplini ile sosyal girişimciliğin toplumun ve bireylerin refahına nasıl katkılarda bulunduğu literatür üzerinden ele alınmaktadır. 


\section{Girişimciliğin Kavramsal Çerçevesi}

Girişimcilik kavramına etimolojik açıdan bakıldığı zaman Fransızca "entreprendre" kelimesinde türetilip İngilizcede "entrepreneurship" halini aldığını görüyoruz. Türkçede ise "üstlenmek" anlamında kullanılmaktadır (Arıkan, 2002'den akt: Ağca ve Yumuşakipek, 2015). Girişimcilik, yeni bir organizasyon oluşturarak veya var olan bir organizasyon içerisinde bazı riskleri göze alarak mevcut pazardaki fırsatları avantaja dönüştürmek için yenilikçi bir bakış ile bir ürünün, hizmetin, uygulamanın dönüştürülme sürecidir. Girişimci ise bu süreç boyunca fırsatları araştıran, yenilik ve değişim düşüncesini bazı riskleri göze alarak uygulamaya, organizasyona dönüştüren kişi olarak ele alınabilir (Bozkurt ve Alparslan, 2013). Girişimcilik uygulamalarına dayalı literatüre göre girişimcilerin sahip olması gereken bazı özellikler bulunmaktadır. Bu ortak özelliklere göre, öncelikle bir girişimci, yenilikçi olmalı ve iyi bir gözlem yeteneğine sahip olmalıdır. Diğer bir özellik ise hızlı düşünme yeteneği olup bu düşünme yeteneği yaratıcılık ile desteklenmelidir. Girişimcinin olmazsa olmazlarından biri de değişim odaklı düşünme ve fırsatlara odaklanmadır. Ayrıca bir girişimci insan kaynaklarını iyi yönetebilmeli, güçlü bir iletişim becerisine sahip olup çok yönlü düşünebilmelidir. Tüm bunların yanı sıra bir girişimci kararlı, azimli, lider özellikli, yüksek bir hayal gücüne sahip olmalıdır (Durmaz, 2015; Bozkurt ve Alparslan, 2013; Günlü, 2015).

Girişimcilikte genel bir kurala göre maddi bir değer yaratmak için olası fırsatları yakalamak ve bu fırsatları değerlendirmek büyük önem taşımaktadır. Girişimcilikle hem toplumun ihtiyaçları karşılanmış olacak hem de birey, bu durumu kendi için bir fırsata çevirip kâr edebileceği kendi organizasyonel yapısını kurmuş olacaktır (Taş ve Menteşe, 2016). Daha geniş bir açıyla bakılırsa girişimcilik bir işe başlamaktan daha fazlasını ifade etmektedir. Girişimciliğin önemli bir yönü olan bir girişim yaratmak, girişimciliğin arka planında yatan resmi tam olarak açıklayamamaktadır. Girişimcilik faaliyetinin arka planındaki hazırlık aşamasına bakıldığında görülmektedir ki fırsatları büyük bir özveri ile araştıran, bu fırsatlara bir değer yükleyen, risk almayı göze alan, yeniliğe uyumlu, azimli ve kararll, toplumu düşünen bir girişimci mevcuttur. Girişimsel bir hareket herhangi bir birey tarafından düşünülebilir ama o 
hareketi eyleme dönüştürmek için büyük bir özveri gerekmektedir. Bu özveriye sahip girişimcilerde amaç yenilikçi fikirlerini örgütsel temelde elle tutulur gerçeklere dönüştürmektir. Söz konusu özveri, bir sivil toplum kuruluşunda, bir örgütsel yapının içinde veya dışında, işletmelerde, mevcut girişimlerde ve birçok alanda sergilenebilir. Girişimciler mevcut olan bir soruna müdahale ederken sorunu ortadan kaldırabilir ya da iyileştirerek topluma değer katacak bir hale getirebilirler.

$\mathrm{Bu}$ bağlamda girişimciliğin önemi özetlenecek olursa öncelikle girişimci toplumla yeni kaynakları ve yeni teknolojileri tanıştırdığı için az kullanılan kaynakların ekonomiye kazandırılmasına imkân sağlar. Ayrıca yeni üretim araçları ve kolları oluşturarak üretimi artırır. Diğer yandan işsizlik sorunu karşısında yeni şirketler açarak veya var olan şirketlerin daha işlevsel hale getirilmesini sağlayarak ülkenin istihdam hacminin attırılmasına katkıda bulunur. Toplumda yeni düşüncelerin oluşturulmasını, yaygınlaşmasını ve toplumsal kalkınma amacıyla uygulanmasını hızlandırır. Böylece ekonomik büyümeyi hızlandırıp yeni iş sahalarının yaratılmasına ve yeni endüstrilerin doğmasına katlı sağlar (Durmaz, 2015).

Girişimcilik faaliyetleri sonucunda ortaya çıkan; dernekler, vakıflar, işletmeler, sivil toplum kuruluşları, organizasyonlar gibi kuruluşlar aynı zamanda sosyal büyümenin, gelişmenin ve kalkınmanın da temelinde yer edinmektedir. Özellikle serbest ekonomilerin olduğu ülkelerde girişimcilere ve girişimlere daha çok ihtiyaç duyulmaktadır. Son yıllarda önemli bir çalışma alanı haline gelen sosyal girişimcilik gelişmiş ülkelerde hızla artan bir girişimcilik türüdür (Özdevecioğlu ve Çingöz, 2009; Şimşek ve Altun, 2020). Son y1llarda devletlerin refah politikalarında da etkin bir rol oynamaya başlayan sosyal girişimcilik, sosyal hizmet gibi gelişmekte olan bir kavram olarak sürekli kendisini yenilemektedir. Girişimcilik çalışmalarının ilk çıktığı zamanlarda sadece bireylerin kendi sermayeleriyle kendi çıkarları doğrultusunda iş kurmaları olarak algılanmakta ve pek itibar görmemekteydi. Son yıllarda devlet politikalarında kendine yer bulan sosyal girişimcilik; daha modern, sistematik kurallarla desteklenmiş oluşumlar haline gelmişlerdir. Dünyada birçok sosyal girişimcinin yıllık bütçesi milyon dolarlara ulaşmaktadır (Taş ve Menteşe, 2016). 


\section{Sosyal Girişimcilik Kavramı ve Özellikleri}

Girişimciliğe yalnızca ticari anlamların yüklendiği, toplumdaki sorunlar karşısında çözüm yolları arayan bireylere hayalperest denildiği dönemlerde sosyal girişimcilik toplumların kalkınması noktasında çok önemli rol oynamıştır. Sosyal girişimciler uzun yıllardır toplumlarda görmeye alıştı̆̆ımız davranışlar karşısında değişime giderek toplumsal dönüşümlere imza atmıştır (Denizalp, 2007). Örneğin henüz sosyal girişimciliğin kavramsallaşmadığı 19. yüzyılda, Florence Nightingale yaptığı faaliyetlerle dünyanın ilk sosyal girişimcilerinden biri olarak kabul edilmektedir. İstanbul'da görev yaptığı yıllarda hastane konusunda ilk hemşirelik okulunu kurarak bir devrim yaratmıştır. Nightingale'nin bu çalışmaları modern anlamda hemşirelik anlayışının temelini oluşturmuştur (Düşünenlerin Düşüncesi, 2013). Ülkemizde de sosyal girişimcilik uygulamalarının eskiye dayandığını görmekteyiz. Örneğin 1872 yılında Darüşşafaka'nın kurulmasında önemli bir rol oynayan Yusuf Ziya Bey'e bir sosyal girişimci diyebiliriz. 1862 yılında kadın hastalıkları ve çocuk hastalıkları ile mücadele etmek amacıyla kurulan Zeynep Kamil Hastanesi'nin kurucusu Prenses Zeynep Kâmil'i de bir sosyal girişimci olarak tanımlayabiliriz (Aksoy, 2013). 1960'larda literatüre giren (Demirel, 2015) ancak sosyal girişimcilik kavramının pek kullanılmadığı bu dönemlerde yapılan bu ve buna benzeri çalışmaları 1980 yılında Amerikan Bill Drayton sosyal girişimcilik olarak tanımlamış ve bu sayede sosyal girişimcilik yükseliş eğilimine başlamıştır. Bu hamleden sonra toplumda farkındalık artmış ve kendilerinde bu alanda potansiyel olduğuna inanan insanlara bir yol açılmıştır (Denizalp, 2007).

Dünya, küreselleşmeyle birlikte hızlı bir değişim ve dönüşüm sürecinden geçmektedir. Yaşanılan değişim ve dönüşümler beraberinde sosyal sorunları da hızlı bir şekilde getirmektedir. İnsan hakları, yoksulluk, gelir adaletsizliğgi, çevre sorunları, krizler, savaşlar, işsizlik gibi birçok alanda ve konuda hala çözülmemiş sorunlar ortaya çıkmaktadır. $\mathrm{Bu}$ sorunlar karşısında devletler kendi başlarına mücadelede yetersiz kalmaktadır. Çünkü sorunlar her ülke için ne kadar ulusal görünse de aslında küresel bir şekilde ilerlemektedir bu nedenle kolayca çözülebilecek sorunlar değillerdir. Bu sorunlar karşısında sivil toplum 
örgütleri ve özel sektörler devletler ile iş birliği yapmaya başlamışlardır. Sivil toplum kuruluşlarının ve özel sektörün sorunların çözümü noktasında önemli katkılar ve çalışmalar yaptığı bilinmektedir. Bu çalışmalar ve katkılarda sosyal sorunlar karşısında sivil toplum kuruluşlarının ve özel sektörün sosyal girişimciliği gündeme taşıdığını söyleyebiliriz (Yumuşakipek, 2015). Öte yandan devletin belli alanlardan çekilmesini sadece yetersiz kalmasına bağlamak yerinde olmayacaktır. Çünkü devletler neoliberal politikaların artan etkisi ile birlikte birçok sektörde küçülmeye gitmektedir. Buna sosyal refah hizmetleri de dahil olup çekildiği alanlara özel sektörün ve sivil toplumun girmesini teşvik etmektedir.

Sosyal girişimcilik, toplumsal problemleri belirleyip onlara çözüm arayan veya sorunların tamamen ortadan kaldırmayı amaçlayan insanların veya kurum ve kuruluşların oluşturduğu kapitalizmin en düşük düzeyde tutulduğu girişimcilik türüdür (Cantekin, 2019). Bünyesinde sosyal ve girişim olmak üzere iki farklı olguyu bulunduran sosyal girişimcilikte, girişimcilik kavramı ticari girişimcilik gibi sorun ve fırsatları fark edip analizini doğru yapma ve yenilikçi yollarla risk alıp çözüme kavuşması anlamına gelmektedir. Sosyal kelimesi ise girişimcilik anlayışının kâr odaklı maksimizasyonu yerine toplumsal sorunlarda ve konularda uyarlanması anlamına gelmektedir. Oluşturulan girişim faaliyeti girişimcilikten dolayı ihtiyaca odaklanmalı, yenilikçi ve yaratıcı olmalıdır; sosyal olmasından ötürü de çıtısı sosyal olmalıdır, bu nedenle sosyal sermayeye gereken önem verilmelidir, kurulacak örgütler sosyal amaç yürütmelidir ve sosyal girişimciler toplum girişimcileri olmalıdır (Akar ve Üstüner, 2017). Bu şekilde sosyal ve girişimcilik kavramı bir bütün olarak hareket etmekte, bu sayede sosyal girişimciler, sosyal sorunlar karşısında girişimcilik odaklı yöntemler düşünen kuruluşlar olarak ortaya çıkmaktadır (Ersen, Kaya, ve Meydanoğlu, 2010).

Girişimcilikte sadece risk almak yoktur onun yanında yenilikçi ve değer oluşturma stratejisi de bulunur. Sosyal girişimcilikte ise kâr ve toplumsal fayda bir arada bulunur. Sosyal girişimciliğin ticari bir girişimcilik olmadığının bilinmesi gerekir. Ticari girişimlerde elde edilen kâra sosyal değer amaçlı fikirler eklenerek o girişimle toplumsal fayda sağlanır. Sosyal girişimcilikte illa özgün fikirler olmasına gerek de yoktur. Yani daha önce gerçekleşmiş olan herhangi bir sosyal girişim üzerinden 
hareket edilebilir (Cantekin, 2019). Sosyal girişimciliğin özellikleri maddeler halinde sıralanırsa eğer, sosyal girişimcilik:

- Toplumları sosyal hedefler doğrultusunda geleceğe hazırlamak

- Sosyal fayda yaratmak

- Sosyal sermayeyi güçlü bir hale getirmek

- Sürdürülebilir ve yenilikçi iş modelleri yaratmak

- Çevre korunmasına katkı sunmak

- Eşitlik, insan hakları, sosyal içerme gibi söz konusu değerleri ön planda tutmak

- Teknolojik gelişimleri desteklemek gibi özelliklere sahiptir (Sarı, 2018).

Sosyal girişimcilik için söz konusu herhangi bir sorun ister ulusal ister küresel olsun o sorunlar çözüme kavuşturulmalı ve dünyanın iyilik hali, sosyal işlevselliği yükseltilmelidir. Sosyal girişimciliğin üzerinde durduğu konular şöyle kategorize edebilir. Sosyal girişimcilik:

- İssizizlik

- Çevre kirliliği

- Sağlıklı yaşayabilme

- Alkol, uyuşturucu ve madde bağımlılığı

- Kadına şiddet

- İnsan hakları

- Eşitlik

- Her türlü kaynağa erişimi sağlama

- Gida ve tarım

- Sosyal politika

- Bilgi hizmetleri

- Sosyal inovasyon ve değişim

- Yoksulluk

- Eğitim ve iş geliştirme

- Toplum servisleri gibi alanlar sosyal girişimciliğin kapsamını oluşturmaktadır (Cantekin, 2019; Aslan, Araza, ve Bulut, 2012).

Sosyal girişimcilik faaliyetlerinin dernek, vakıf, özel sektör, belediyeler, kamusal kurumlar, sosyal amaçlı örgütler gibi birçok farklı şekilde gerçekleştiği için çalışma kapsamı buna paralel olarak geniş olmaktadır. 


\section{Sosyal Hizmet Kavramı}

Sosyal hizmetin kaynağını insanlar arasındaki paylaşım duygusu oluşturur. Dinsel-toplumsal duygular, acıma duygusu, yardımlaşma, insan onuruna bağlllık, öte dünya bilinci, topluluk olma bilinci gibi duygular sonucunda insanlar, yüzyıllardır toplumdaki hizmetlerden ve imkânlardan yararlanamayan; yoksul, engelli, işsiz vb. gruplarda sayabileceğimiz insanlara yardım etmiştir. $\mathrm{Bu}$ durum toplumsal durumdan kaynaklı acının bir nebze de olsa giderilmesine imkân tanımıştır. Günümüzde refah politikaları haline gelmeden uzun zaman önce sosyal hizmet çalışmaları dini kurumlar ve kısmen devlet tarafından yürütülmekteydi. Sanayileşme ile birlikte artık devlet politikalarında sosyal hizmet uygulamaları daha fazla yer edinmeye başlamıştır. Bu geçişte en büyük etkiyi insanların hak arayışları oluşturmuştur. Sanayileşme sonucunda ortaya çıan zor çalışma koşullarına karşı işçi ve emekçilerin hakkını belirleyen sosyal mücadeleleri, grevler, yükselen sosyalist hareketler, sosyal hukuk devletini elzem kilmıştır (Şeker, 2015). İlk sosyal refah kurumlarını ise 1800'lü yıllarda kentsel bölgelerde yaşayan insanların ihtiyaçlarını karşılamak için oluşturulan sosyal girişimlerle görüyoruz. Yine bu girişimler din adamları ve inançsal örgütler aracılığıyla kurulmuştur. 1820 yılında John Griscom tarafından Yoksulluğu Önleme Derneği kurulmuştur. Bu dernek ilk sosyal refah örgütlenmesi kurumu olarak kabul edilmektedir. $\mathrm{Bu}$ derneğin kuruluşunda; yoksul insanların yaşan koşullarını araştırmak, kendi kendilerine yetebilecek duruma gelmelerine yardımcı olacak planlar oluşturmak ve onları ekonomik davranmaya cesaretlendirmek gibi amaçlar yer almıştır. 1800'lü yılların ikinci yarısında ise büyük kentlerde özel inanç kurumları kurulmuştur. Bu kurumlar yoksullara, işsizlere, yetimlere ve özürlü bireylere yardım etmek amacıyla kurulmuştur. Bu kurumların en dikkat çekeni İngilizlerde olan Hayırseverlik Örgütleme Cemiyeti - Charity Organization Society ( COS)'tur. Bu cemiyet İngiltere'den sonra Amerika' da da hızlıca yayılmaya başlanmıştır. COS hareketine paralel olarak aynı dönemlerde Londra' da yerleşim evleri adı altında bir sosyal girişimcilik faaliyeti başlamıştır. İlk olarak 1884 yılında Toynbee Hall adıyla kurulan yerleşim evleri, kentte bulunan yoksul bölgelerde yaşayarak eğitim merkezleri kurdular ve bu bölgedeki 
olumsuz yaşam koşullarını nasıl iyileştirebilecekleri konusunda çalışmalar, araştırmalar yürüttüler. Bir sosyal girişimle kurulan yerleşim evleri sosyal hizmet kuruluşları görev eğilimli bir yaklaşım sergileyerek toplumsal kalkınmaya katkıda bulundular. 1898 yılında ilk eğitim kursu New York Hayırseverlik Örgütleme Cemiyeti tarafından işçilere verildi. 1904 yılında okul tarafından bir yıllık program uygulandı. Bu tarihten itibaren birçok üniversite ve meslek yüksekokulunda sosyal hizmet eğitimleri verilmeye başlandı ve sosyal hizmet günümüze kadar sürekli bir değişim, dönüşüm yaşayarak ilerlemeye, gelişmeye devam etmiştir (Zastrow, 2014). Öte yandan 18. ve 19. yüzyıllarda yaşanan Fransız İhtilali ve Sanayi Devrimi gibi ekonomik ve toplumsal gelişmeler ile kilisenin ve ailenin sosyal hizmetlerdeki rolü azalmıs, hayırseverlik bağlamında yürütülen hizmetler kurumsallaşmış ve sosyal hizmet mesleğinin gelişimini hızlandırmıştır.

Sosyal hizmet meslek ve disiplininin sahip olduğu yaklaşımların başlangıç noktası, insanların sosyal bir varlık olduğundan çıkmaktadır. İnsanlar gerçekten de sosyal canlılardır. Bu özelliklerinden dolayı birçok ihtiyacını karşılama noktasında başka insanlara ihtiyaç duymaktadır. Bireylerin gelişimi ve ilerlemesi için diğer insanlarca yerine getirilen rehberlik, koruma ve eğitime ihtiyaç duyulur. Fiziksel ve psikolojik açıdan ne kadar güçlü olursa olsun, bir insanın varlığı başka insanların eylem ve seçimlerine bağlıdır. Bu noktada insanların karşılıklı bağımlılığı ile sosyal ilişkilerinin etkinliğini ve gücünü, başka bir deyişle sosyal işlevselliklerini arttırmada yardım etmeye odaklanmış bir mesleğin temelidir (Sheafor and Horejsi, 2015). Sosyal hizmet faaliyet alanını gruplandırmaya ayırırsak eğer üç düzeyde uygulama yaptığını görmekteyiz. Bunlar: Mikro; birey ile birebir çalışma, mezzo; ailelerle ve diğer küçük gruplarla çalışma ve makro; örgütler ve topluluklarla çalışma şeklindedir (Zastrow, 2014).

Sosyal hizmet meslek ve disiplini yukarıda saydığımız gibi toplumdaki farklı alanlarda çalışma yürütmektedir. Sayılan bu alanlar daha spesifik olarak ifade edilirse şöyle sıralanabilir; gençlik ve gençlik refahı alanı, sağlık alanı, aile ve aile refahı alanı, eğitim alanı, suçluluk alanı, çocuk ve çocuk refahı alanı, adalet alanı, mülteci alanı, engelliler ve engelliler refahı alanı, çalışma ve sosyal güvenlik alanı, toplumsal 
sorunlar, sosyal yardım alanı, yaşlılık ve yaşlı refahı alanı, gençlik ve gençlik refahı alanı gibi alanlarda faaliyet yürütmektedir (Apak, 2018).

\section{Sosyal Girişimcilerin ve Sosyal Çalışmacıların Sahip Oldukları Ortak Roller ve Değerler}

Bir sosyal girişimci toplumsal ihtiyaçlar karşısında kâr amacı gözetmeden girişimsel özellikler kullanarak yaratıcı uygulamalar ve fikirlerle yeni yapılar ve süreçler oluşturur ve faaliyete geçirir. Yaşadığı toplumdaki aksaklıkları fark eder ve o aksaklıkların üzerine giderek sorunun kaynağına kadar iner. Sorunu kaynağından çözebilmek için proje üretir veya yeni yöntemler dener (Özdevecioğlu ve Çingöz, 2009). Bir sosyal girişimcinin bunu yaparken bazı özelliklere sahip olması gerekir. Bu özelliklerin başında toplumsal problemlerin farkında olma ve sorumluluk sahibi olma gelmektedir. Ayrıca bir sosyal girişimci doğal bir aktivist olup mücadeleci ve azimli bir karaktere sahip olmalıdır. Başarılı olma arzusuna sahip olmakla birlikte sorumluluk sahibi olmak da sosyal girişimcinin özellikleri arasındadır. Ayrıca bir diğer özellik olarak fırsatları sezebilme ve yaratıcı olma ön plana çıkmaktadır. Tüm bunların yanı sıra bir sosyal girişimci ihtiyaç ve çözüm odaklı olmak, risk alabilen, ekip çalışmasına yatkın, araştırma yönü olan, güven veren, eksik yönlerini ve sınırlarını bilen, başkalarını etkileyebilmek gibi özelliklere sahip olmalıdır (Denizalp, 2007).

Sosyal çalışmacı ise; aile, birey, grup ve toplumlarla çalışarak onların sorunlar karşısında baş etme yeteneklerini artırarak sosyal işlevselliklerini iyileştirip koruma ve geliştirme altına alan, sosyal değişimi destekleyen, toplumların gelişmesine katkı sağlayan, insan hakları ve onurunu dikkate alarak yaşam kalitesini yükselten, insanlarla kaynakları buluşturan, insanların ihtiyaçlarının giderilmesi noktasında yaratıcı davranıp sosyal politikalar oluşturan ve geliştiren nitelikli meslek elemanlarıdır (Cılga, 2004). Sosyal çalışmacıların da sahip olması gereken bazı ortak özellikleri bulunmaktadır. Bunlardan biri toplumsal sorunlar karşısında duyarlı olmaktır. Ayrıca toplumda mevcut olan problem ve ihtiyaçların farkında olmak ve o doğrultuda problemlere çözümler üretebilmek sosyal çalışmacının özellikleri arasında yer almaktadır. Bir sosyal çalışmacı aktif bir dinleme becerisi ve gelişmiş iletişim becerilerine sahip olmalı, insanlarla iyi iletişim kurup kendini iyi ifade edebilmelidir. Ayrıca sosyal 
çalışmacıların empati yeteneği gelişmiş olmalı, insan ilişkileri, davranışı ve gelişimi hakkında bilgi sahibi olmalıdır. Tüm bunların yanı sıra sosyal çalışmacılar hızlı ve doğru vermek, sorunlar karşısında toplumsal değer ve normlara göre hareket etmek, planlama ve organizasyon becerilerine sahip olmak, yardımsever, anlayışlı ve hoşgörülü olmak, kriz durumlarında verimli çalışabilmek gibi özelliklere sahip olmalıdırlar (Koç, 2015)

Hem sosyal girişimciler hem de sosyal hizmet meslek elemanları bireylerle, gruplarla, ailelerle ve topluluklarla çalışırken bazı rol ve işlevleri üzerlerinde bulundurmaları gerekmektedir. $\mathrm{Bu}$ rollerden bazılarının her iki meslek alanında da ortak olduğu görülmektedir.

Bunlardan ilki "bağlantı kuruculuk (aracı) rolü" olup birey ile kaynakların durumunu değerlendirir. Değerlendirme sonucunda birey ile toplum hizmetleri arasında bağlantı kurdurur (Duyan, 2014).

Bir diğer rol ise "savunuculuk rolü"dür. Bu rol sosyal hizmetin hukuk disiplininden aldığı bir kavramdır. Sosyal girişimciliğin ise doğasında olan toplumdaki bireylere destek verme bağlaminda sahip olduğu bir roldür. Toplumdaki bazı bireyler, gruplar yardıma ihtiyaç duydukları zaman gerekli kuruluşlardan gereken, istenilen hizmeti alamamaktadır. $\mathrm{Bu}$ noktada sosyal girişimciler ve sosyal çalışmacılar yaşanılan mağduriyetin giderilmesi noktasında; vaka savunuculuğu, sınıf savunuculuğu veya toplum savunuculuğu yaparlar (Zastrow, 2014).

Sosyal girişimciler ve sosyal hizmet meslek elemanları, bireylerin veya grupların ihtiyaçlarını dile getirme, sorunlarını belirleme ya da açı bir şekilde dile getirebilmeleri için çözüm stratejileri geliştirir ve uygularlar. $\mathrm{Bu}$ sayede bireylerin ve grupların kendi problemleriyle daha etkili bir şekilde ilgilenebilmeleri için kapasitelerinin geliştirilmesine yardımcı olunur (Sheafor and Horejsi, 2015).

Bir başka ortak rol ise "yönetici rolü" olup yönetimde, kurum dışı veya kurum içinde program geliştirme, politikalar üretmeyi ifade etmektedir (Duyan, 2014).

"Sosyal değişme ajanı rolü" bir başka ortak roldür. Bu rol gereği hem sosyal çalışmacılar hem de sosyal girişimciler sosyal problemlerin ve politikaların analizlerini yaparlar. Bu sayede toplumunun ilgisi harekete geçirilir ve sosyal kaynakların geliştirilmesi amaçlanır (Duyan, 2014). 
Diğer bir rol ise "aktivist rolü" dür. Bu çerçevede bir sosyal girişimci ve çalışmacı toplumdaki sosyal adaletsizliklerle, eşitsizlik konularıyla ilgilenirler. Bu konularda strateji geliştirmelerinin amacı toplumdaki ihtiyaçların karşılanması için sosyal çevrenin değiştirilmesidir (Zastrow, 2014).

Bir başka ortak rol ise "güçlendirme rolü"dür. Bireylerin yaşam şartlarını destek ve düzenleme sürecinde sosyal girişimciler ve sosyal hizmet meslek elemanları; bireylerin sorumluluk almalarında, seçim yapmalarında ve bireylerin kendi ayaklarının üzerinde durabilecek güçte olmalarını sağlamak için kapasitelerini artırıcı bir rol oynarlar (Erbay, 2018).

Ortak rollerden bir diğeri ise "eğitim rolü" olup eğitimler sayesinde toplumdaki sosyal sorunlar hakkında kamuoyu oluşturulup farkındalık kazandirılır (Duyan, 2014).

Örneğin dünyada ve Türkiye'de en önemli sorunların başında gelen kadın yoksulluğuna yönelik Balıkesir' in Ayvalık ilçesinde uygulanmaya başlamış bir sosyal girişim ile kadınların yoksulluğunu azaltmak ve iş yaşamlarına katılımı desteklemek hedeflenmektedir. ÇÖP(M)ADAM adı verilen bu sosyal girişim ile kadınlar atıklardan farklı ve yeni bir model çantalar tasarlamakta ve üretmektirler. Elde edilen gelirler ile hem kadın girişimciler desteklenmekte hem de çevre korunmaktadır (Özeren ve Saatçioğlu, 2016; ÇÖPMADAM, 2020). Bu örnekte görüldüğü üzere kadınların girişime dahil edilmesi ile sosyal çalışmacının bağlantı kuruculuk rolü, iş hayatına katılımının ve gelir elde etmelerini sağlanması ile güçlendirme rolü, çevrenin korunması ile savunuculuk rollerinin bir sosyal girişim bünyesinde ortaya çıtığı görülmektedir.

\section{Sosyal Girişimcilik ve Sosyal Hizmet Arasındaki İlişki}

Sosyal hizmet mesleği dezavantajlı bireylerin karşılaştıkları sorunların çözülmesini ve toplumla bütünleşmelerinin gerçekleşmesini hedeflemektedir (Aykara ve Akçay, 2010). Sosyal hizmet mesleği, sosyoekonomik politikaların toplumda ve bireylerde yol açtığı olumsuz durumlarla ilgilenir. Mesleğin özüne inersek eğer toplumdaki alt gelir gruplarının ve diğer dezavantajlı grupların yaşadığı toplumsal sorunlariyla var olmuştur. Sosyal hizmet mesleği bu yönüyle toplumdaki işlevini yerine getiremeyen veya kısmen getiren sosyal politikalara yer yer 
muhalif konumdadır yer yer ise taraftır. Tek bir genel amacı vardır oda toplumdaki olanakların bütün bireyler açısından eşit olarak dağıtılması ve bireylerin onlardan yararlanabilmesidir. Eşitlik ve özgürlük konusunda toplumsal sorunlar kalıcı çözümler üretir. Bu yönleriyle sosyal refah kuruluşlarının oluşturulmasında destekleyici ve savunucu bir rolü bulunur. İnsanların sürekli artan sosyal hizmet ihtiyaçlarını toplumdaki girişimlere destek vererek topyekûn bir mücadele anlayışını aktif hale getirir. Bu noktada sosyal girişimler sosyal hizmet üretimi için gerekli kaynakları bir araya getirir ve kaynaklarla müracaatçı1 tıpkı sosyal hizmet mesleği gibi buluşturur. Her sosyal girişimci aynı zamanda sosyal hizmet meslek elemanlarının sahip olduğu bağlantı kurucu rolüne de sahiptir bu özelliğiyle. Sosyal hizmet mesleği nasıl ki müracaatçının yaşadığı sorunlar karşısında hayırseverlik yaklaşımıyla değil de sorunu temelden çözecek hak temelli yaklaşımı tercih ediyorsa sosyal girişimcilikte insanlara balık vermeyi değil balık tutmayı öğretmektedir. Hem sosyal hizmet meslek eleman hem de sosyal girişimci toplumdaki aksaklıklardan ortaya çıkmış sorunlar karşısında gerekirse yeni müdahale yaklaşımları oluşturarak o sorunun üzerine gider. Sosyal hizmet meslek elemanı yeni bir yaklaşım, yöntem veya yeni bir politika geliştirirken sosyal girişimci ise yeni bir proje geliştirir. Bu sayede sorunun tek seferlik ortadan kaldırılmasına değil temelden çözülmesine aracılık ederler. Her iki alanda toplumsal sorunlar karşısında insanlarla kaynakları buluşturur, topluma yeni kaynaklar sunarlar. Sosyal hizmet meslek elemanları nasıl ki müracaatçılarıyla görüşürken ihtiyaçlarının belirlenmesinde özveriyle hareket edip sosyal inceleme raporları yazıyorsa bir sosyal girişimci de toplumdaki insanların ihtiyacının ne olduğu konusunda aynı özveriyle hareket ederek araştırmalar yapar. Sosyal hizmet ile sosyal girişimcilik çalıştığ 1 alanlar konusunda da paralellik gösterirler. Bir sosyal girişimci; insanların sağlıklı bir şekilde barınmasına, alkol uyuşturucu gibi madde bağımlılığıyla, kadına şiddette, işsizlikte, yoksullukta insan haklarında vb. birçok alanda faaliyet yürütür. Saydığımız bu alanlar sosyal hizmetinde aktif olarak çalıştı̆̆ alanların içerisindedir. Bu bağlamda sosyal girişimcilik ve sosyal hizmet meslek ve disiplini toplumdaki sosyal değer temelli sorunlar karşısında hareket eder. Her bir sosyal sorun karşısında başlatılan sosyal girişimcilik faaliyeti aynı zamanda bir sosyal hizmet uygulamasıdır. Sosyal girişimciliğin; toplumların kalkınması, 
bireylerin sosyal işlevselliklerinin yerine getirilmesi, sosyal politikaların oluşturulması, sosyal belediyecilik girişimlerini başlatması, güçlendirme yaklaşımıyla hareket etmesi, toplumsal istikrarın sağlanması, sosyal refah oranının yükseltilmesi, sosyal koşulların geliştirilmesi, adil ve eşit bir gelir dağıtımının sağlanması gibi birçok faaliyeti de sosyal hizmet alanıyla iç içe hareket ettiğinin ve birbirlerini tamamlayıcı özelliklerde olduğunun göstergesidir.

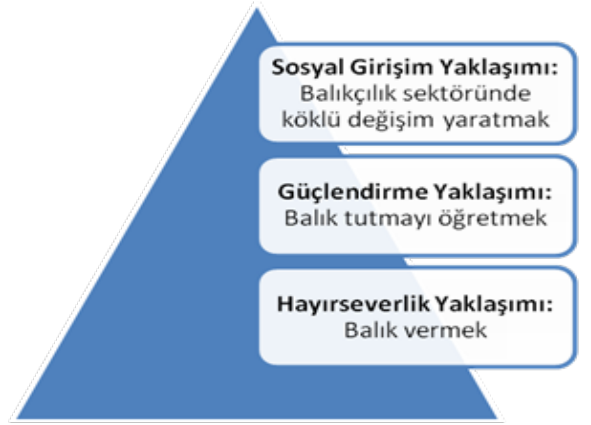

Şekil 1.Sosyal Girişim Yaklaşımı

Kaynak: Denizalp, Hülya. Toplumsal Dönüşüm için Sosyal Girişimcilik Rehberi, STGM 2009.

Örnek olarak, Adana'da kurulan bir sosyal girişim olan Genç Engelliler Gençlik ve Spor Kulübü hem engelli hem de engelsiz gençlerin farklılıklarıyla bir arada olabilecekleri bir alan ortaya koyarak birlikte güçlenmelerini hedeflemektedir. Bu bağlamda kulüp kurulduğu 2005 yılından beri engelli ve engelsiz gençlere yönelik yüzlerce spor, sanat, eğitim faaliyeti gerçekleştirmiştir. Bu faaliyetlerde engelli bireylerin eğitmen, antrenör vs. olarak yer alması sağlanmış böylece önyargıları yıkılması amaçlanmıştır. Bu sayede kulüp katılımcısı olan gençler günlük hayatlarında engelli haklarının gönüllü birer savunucu olmuşlardır (Yalçın, 2018, s.15).

\section{Toplum Kalkınmasında Sosyal Hizmet ve Sosyal Girişimcilik}

Sosyal girişimcilik ve sosyal hizmet meslek ve disiplini, toplum kalkınması kavramında gerek uygulaması noktasında gerek amacı doğrultusunda birçok benzerliklere sahiptir. Sosyal girişimcilik, toplumları sosyal hedefler doğrultusunda geleceğe hazırlar. Geleceğe 
hazırlarken amaç sosyal fayda yaratmaktır ve toplumun kalkınmasına destek olmaktır. Sosyal girişimcilik faaliyetleriyle sosyal sermaye daha güçlü bir hal alarak sürdürülebilir ve yenilikçi iş modelleri yaratılır. Sosyal girişimcilik faaliyetlerinde de gördügümüz gibi toplum kalkınması yaklaşımı, toplumları sorunlar karşısında kendi girişimleriyle çözüme ulaşmasına yöneltir. Bu noktada sosyal hizmet meslek ve disiplini ile eş amaca yöneliktir. Toplum kalkınması, sosyal hizmetin az gelişmiş toplumlarda yürüttüğg̈ uygulamalardan biri olarak ele alınabilir. Bu durumda sosyal hizmet ile sosyal girişimciliğin tekniklerinin toplum kalkınması ile çakışır duruma gelmektedir. Toplum kalkınması en başlarda sosyal hizmetten ayrı ele alınırdı ama zamanla bilimsel bir dayanak ve içeriğe dayanma ihtiyacı duydukça sosyal hizmet ile toplum kalkınması birbirine yaklaşmıştır. Toplum kalkınması etkinlikleri, bilimsel ve sistematik şekilde ele alındığında uygulanan model; toplum örgütlenmesi modelidir. Toplum örgütlenmesinin en önemli sağlayıcılarından birini de sosyal girişimler oluşturmaktadır. Toplum kalkınmasında sosyal hizmet ve sosyal girişimciliğin uygulamalarında benzer noktalar vardır. Bunlar:

- Toplumu iyi tanımak ve toplum hakkında bilgi toplamak

- Sorunlar karşısında toplumu bilinçlendirmek

- İnsanları güçlendirici yaklaşımlarla insanların sorunlar karşısında konuşabilmelerini, harekete geçmelerini teşvik etmek

- İnsanların kendilerine olan güven duygusunun geliştirilmesi

- Toplum kalkınması için planlı, programlı bir hareket programının belirlenmesi

- İnsanlara kendi sorunlarını çözme noktasında yeteneklerinin artırılması, iyileştirilmesi

- Güçlü ve zayıf noktaların belirlenmesi

- Sivil toplumu güçlendirmek

- Yenilikçi çözümler geliştirmektir.

Zamanla toplum kalkınması konusunda ülkelerin ilgisi artmış ve bu doğrultuda programlarını genişletmişlerdir. Toplum kalkınmasında gençlerin ve kadınların rolü de zamanla kabul edilmiştir. Üniversiteler, akademik araştırmalar bu konuya daha fazla yönelmiştir. Yaşanan bu gelişmelere ve sosyal hizmet ile sosyal girişimciliğin toplum kalkınmasındaki ortak noktalarına baktığımızda; toplum kalkınması için 
ihtiyaç duyulan yeni tip toplum görevlilerini oluşturmaktadır. Bu yeni tip; insanlarla kaynaşabilen, toplumu tanıyan, empati yapabilen, yardıma hazır sosyal girişimcimler ve sosyal hizmet meslek elemanlarıdır (Kongar, 1972).

Bu çerçevede Nobel ödüllü ekonomist Muhammed Yunus'un hayata geçirdiği Grameen Bankası toplum kalkınmasına yönelik iyi bir sosyal girişimcilik örneğidir. İlk olarak Bangladeş'te ortaya çıkan Grameen Bank dünyanın birçok ülkesinde küçük miktar kredilerini teminatsız ve düşük faiz oranı yoksul insanlara vermektedir. Tutar olarak çok küçük olsa da yoksul insanların desteklenerek açlık sınırından uzaklaşılması hedeflenmektedir. Bu bankanın en büyük sosyal faydası, sosyal dışlanmış bireylere işgücü piyasasına dahil olmasına aracılık etmesidir (Kümbül, 2011). Bu bağlamda sosyal hizmetin toplum kalkınması hedeflerine ulaşması için sosyal girişimlerinin önemli bir araç olduğu söylenebilmektedir.

\section{Sonuç}

Sosyal girişimcilik kavramı son yıllarda sıkça duyulan ve birçok sektörün ilgisini üzerine çeken bir olgu haline gelmiştir. Dünyada yaşanılan gelişmeler, değişimler beraberinde yoksulluk, işsizlik, insan hakları ihlali, çevre sorunları, adaletsizlikler gibi birçok sosyal sorunu da ortaya çıkarmıştır. Devletler bu sorunlar karşısında yeterli önlemleri alamamakta ve uyguladıkları hizmetler yetersiz kalmaktadır. Sosyal girişimciler de tam bu noktada devreye girerek devletle, özel sektörle, sivil toplumla iş birliği yaparak toplumsal sorunlara toplumsal çözümler üretmeye başlarlar. Çünkü sosyal girişimcilik toplumun sosyal ihtiyaçlarına odaklanan, sorunlar karşısında çözüm bulmakla beraber kâr amacı gözetmeyen çalışmalardır. Küresel gelişmelerin sonucunda birçok sosyal sorun, sosyal girişimciliği ortaya çıkarmıştır, bunun yanında küresel ilerlemenin getirmiş olduğu olumlu gelişmelerde sosyal girişimciliğin hızlıca yayılmasını sağlamıştır. Bu gelişmeler; internet, hizmet sektöründeki artış, bilgi teknolojilerinin gelişmesi, bağımsız yaşam şeklinin yaygınlaşması, girişimcilik eğitimlerinin artması, sivil toplum anlayışının gelişmesi gibi durumlardır. Sayılan bu gelişmeler sosyal girişimciliğin hızlıca yayılmasına olanak tanımıştır. 
Sosyal girişimciliğin temel odak noktası toplumun sosyal ihtiyaçlarını gidermek ve sosyal sorunlara çözüm bulmak olduğu için sosyal hizmet meslek ve disipliniyle birçok yönden çakışmaktadır. Sosyal hizmetin doğasına bakıldığı zaman sosyal girişimcilik faaliyetlerini de içinde barındırdığını görüyoruz. Sosyal hizmet meslek ve disiplini de refahın yükseltilmesi için toplumsal değişimi sağlamaya çalışır. Toplumsal değişmeyi sağlarken insan ilişkilerinde güçlendirme yaklaşımı önemli bir yer tutar. Bu yaklaşım ile bireylerin sosyal sorunlar karşısında baş etme yeteneği geliştirilmeye çalışılır. Sosyal hizmetin merkezinde ise insan hakları ve sosyal adalet ilkesi vardır. Bu iki ilke sosyal hizmet mesleğine tıpkı sosyal girişimcilik gibi toplumsal bir sorumluluk yükler. Sosyal girişimcilerin de topluma, insanlığa ve çevreye fayda sağlamayı amaçlamasının yanında toplumsal birlik ve beraberliğin sağlanması noktasında önemli sorumluluklar yüklendiğini görmekteyiz. Sosyal hizmet ve sosyal girişimcilik faaliyetleri kapitalist sistemlerin iyi yönlerini toplum yararına kullanmaya çalışır. Her iki alanda da kâr kavramı toplumsal sosyal fayda ve sosyal sermaye olarak algılanır. Sermayenin toplum için kullanılması toplumsal kalkınmayı destekler ve toplumu harekete geçirir.

Sosyal hizmetin makro düzeyde uyguladığ 1 faaliyetler ile sağlamaya çalıştığı toplumsal kalkınmayı gerçekleştirmek ve gelişimini sağlamak için sosyal girişimciliğin de gelişmesi gerekmektedir. Çünkü sosyal girişimcilik, girişimcilik faaliyetleri gibi sadece üretim faktörlerini bir araya getirmez. Örneğin düşük gelirli bölgelerde yaşayan insanlar için açtıkları okullarda uygun bir ücretle kaliteli eğitim almaları salt bir girişimcilik faaliyeti değildir; amacı kâr elde etmekten ziyade sosyal adaleti sağlamaktır. Sosyal adalet ise sosyal hizmetin temel ilkesidir, bu bağlamda sosyal girişimcilerin yaptığı bir uygulamadaki sosyal hizmetin temel ilkesi görülmektedir. Sosyal hizmet ile sosyal girişimciliğin birçok ortak yönünün bulunması, faaliyet gösterdikleri alanların ortak olmasından da kaynaklanmaktadır. İnsan hakları, yoksulluk, işsizlik, kadınlar, işçiler, gençler gibi alanlar sosyal girişimcilik ve sosyal hizmet için ortak çalışma alanlarıdır.

Yoksulluk karşısında sadece devlet kaynaklarından yararlanmak kalıcı bir çözüm olmamaktadır. Sosyal girişimcilerin oluşturduğu sosyal yenilikçi çözümler, yoksulluk sorunuyla başa çıkma noktasında çok 
önemli gelişmelere destek olmaktadır. Bir sosyal girişimci bunu yaparken sosyal hizmet meslek elemanlarının sahip olduğu birçok rolü de üzerinde taşımaktadır. Aktivist, savunucu, güçlendirici, destekleyici, eğitici gibi roller her iki alanda faaliyet yürüten kişilerde ortak bulunan vasıflardır.

İnsanların iyilik durumunu artırıp sosyal işlevselliklerini gerçekleştirmeye çalışan sosyal hizmet mesleği ile çalışma yaptıkları konularda kalıcı değişimler yaratarak bir sosyal sorunu ortadan kaldırmayı amaçlayan sosyal girişimcilik faaliyetleri birbirini tamamlayan iki alandır. Sosyal hizmet mesleğinin bir yönü bireylere yardım etmek olarak kabul edilir, bir diğer yönü de sadece yardım etmeyi değil; bireyi güçlendirerek ve yaşadığ1 sorun karşısında politikalar, stratejiler geliştirerek sorunun ortadan kalkmasına ve bireylerin kendi kendilerine sorunlar karşısında baş etme gücüne sahip olmalarını sağlar. Sosyal girişimcilikte tıpkı sosyal hizmetin ikinci yönü gibi hayırseverlik anlayışıyla hareket etmeyerek; balık vermek yerine balık tutmayı öğretir. Her iki alan ve her iki alanın faaliyet gösterdiği meslek elemanları birçok ortak özelliğe sahiptirler. Toplumsal kalkınmanın gerçekleştirilmesi için sosyal hizmet meslek ve disiplininde, sosyal girişimcilik yeni bir alan olarak işlenmeli ve öğrenilmelidir. 


\title{
EXTENDED ABSTRACT
}

\section{Evaluating the Relationship Between Social Entrepreneurship and Social Work}

\author{
Enes Apaydın - Fatih Altun \\ Bandırma Onyedi Eylül Üniversitesi
}

With globalization, rapid changes and transformations have been experienced in many areas. Changes in transportation and communication fields have eroded the borders between world markets. World markets have become more accessible and this situation has created many new opportunities for entrepreneurs. One of the most important of these opportunities has been the expansion of existing business boundaries, where entrepreneurs can reach anywhere in the world. In parallel with the developments in information technologies, entrepreneurs have started to access broader and faster information about the society. They increased their entrepreneurial activities by using this information they obtained in the production of products and services that will add value to the society. On the other hand, the rapid development of globalization and information technology has increased the free movement of goods, capital and people, thus causing an increase in global competition. The effect of global economic competition has started to show itself more and more in the society. Entrepreneurs who exist in such an environment have adopted the strategy of adapting to the current order in order to survive. The main focus of this strategy is the concept of innovation.

On the other hand, the concept of social entrepreneurship has become a phenomenon that has been frequently heard in recent years and attracts the attention of many sectors. Developments and changes in the world have brought along many social problems such as poverty, unemployment, human rights violations, environmental problems, injustices. States cannot take adequate measures against these problems and the services they provide are insufficient. Social entrepreneurs step in 
at this point and start to produce social solutions to social problems by collaborating with the state, private sector and civil society. Because social entrepreneurship is a work that focuses on the social needs of the society, finding solutions to problems, but not for profit. As a result of global developments, many social problems have revealed social entrepreneurship, besides, the positive developments brought about by global progress have enabled social entrepreneurship to spread rapidly. These developments; Internet, the increase in the service sector, the development of information technologies, the widespread use of an independent lifestyle, the increase in entrepreneurship education, and the development of civil society understanding. These developments have enabled social entrepreneurship to spread rapidly.

Since the main focus of social entrepreneurship is to meet the social needs of the society and find solutions to social problems, it overlaps with the social work profession and discipline in many ways. When we look at the nature of social work, we see that it includes social entrepreneurship activities. Social work profession and discipline also tries to provide social change in order to increase welfare. Empowerment approach takes an important place in human relations while providing social change. With this approach, the ability of individuals to cope with social problems is tried to be developed. At the center of social work is the principle of human rights and social justice. These two principles impose a social responsibility on the social work profession, just like social entrepreneurship. We see that social entrepreneurs also have important responsibilities in terms of ensuring social unity and solidarity, as well as aiming to benefit society, humanity and the environment. Social work and social entrepreneurship activities try to use the good aspects of capitalist systems for the benefit of society. In both areas, the concept of profit is perceived as social social benefit and social capital. The use of capital for society supports social development and mobilizes society.

Social entrepreneurship also needs to be developed in order to realize and develop the social development that social work tries to achieve with the activities applied at macro level. Because social entrepreneurship does not only bring together production factors like entrepreneurship activities. For example, it is not just an entrepreneurial activity for people living in low-income regions to receive quality education at an affordable 
price; its aim is to achieve social justice rather than profit. Social justice is the basic principle of social work. In this context, the basic principle of social work in an application performed by social entrepreneurs is seen. The fact that social work and social entrepreneurship have many common aspects is also due to the fact that the areas they operate in are common. Areas such as human rights, poverty, unemployment, women, workers, youth are common working areas for social entrepreneurship and social work.

Utilizing only state resources is not a permanent solution against poverty. Social innovative solutions created by social entrepreneurs support very important developments in dealing with the problem of poverty. While doing this, a social entrepreneur bears many roles that social work professionals have. The roles such as activist, advocate, empowering, supportive, and educator are common qualifications among people working in both fields.

The social work profession, which tries to increase the well-being of people and realize their social functionality, and social entrepreneurship activities that aim to eliminate a social problem by creating permanent changes in the subjects they work with are two complementary fields. One aspect of the social work profession is considered to be helping individuals, another aspect is not just helping; It ensures that the problem is solved by empowering the individual and by developing policies and strategies against the problem he / she is experiencing, and that individuals have the power to cope with the problems themselves. By not acting with the understanding of philanthropy in social entrepreneurship just like the second aspect of social work; teaches to fish instead of giving fish. Both fields and professionals in which both fields operate have many common characteristics. Social entrepreneurship should be studied and learned as a new field in social work profession and discipline in order to realize social development.

\section{Kaynakça / References}

Ağca, V., ve Yumuşakipek, H. D. (2015). Günümüzde girişimcilik trendini yükselten güçler. E. Kaygın, ves. B. Güven içinde, Girişimcilik: Temel Kavramlar, Girişimcilik Türleri, Girişimcilikte Güncel Konular (s. 9-65). İstanbul: Siyah İnci Akademi. 
Akar, H., ve Üstüner, M. (2017). Mediation role of self-efficacy perceptions in the relationship between emotional intelligence levels and social entrepreneurship traits of pre-service teachers. Journal of Education and Future, 12, 95-115.

Aksoy, T. (2013, Ocak 29). Sosyal girişimcilik nedir? 08.05.2020 tarihinde Temelaksoy Web Sitesi: https://www.temelaksoy.com/sosyalgirisimcilik-nedir/ adresinden alındı

Anduyo, C. (2016, Şubat 15). Social Entrepreneurship. 05 08, 2020 tarihinde Prezi Web Sitesi: https://prezi.com/zeuq7bdfsim0/social-entrepreneurship/ adresinden alınd 1

Apak, H. (2018). Sosyal Hizmet ve Maneviyat. İstanbul: Bir Yayıncllk.

Aslan, G., Araza, A., ve Bulut, Ç. (2012). Sosyal girişimciliğin kavramsal çerçevesi. Girişimcilik ve Kalkınma Dergisi, 7(2), 69-88.

Aykara, A., ve Akçay, S. (2010). Kronik hastalığı olan bireylerin toplumla bütünleşmelerinde sosyal hizmet uygulamaları. Ufkun Ötesi Bilim Dergisi, 10(1-2), 51-56.

Aylanç, M. (2018, Aralık 9). Sosyal girişimcilik. 08.05.2020 tarihinde Prezi Web Sitesi: https://prezi.com/p/0-ewoyih0ufi/sosyal-girisimcilik/ adresinden alınd 1

Bozkurt, Ö. Ç., ve Alparslan, A. M. (2013). Girişimcilerde bulunması gereken özellikler ile girişimcilik eğitimi: Girişimci ve öğrenci görüşleri. Girişimcilik ve Kalkınma Dergisi, 8(1),7-29.

Cantekin, B. (2019, Aralık 3). 07.05.2020 tarihinde İstanbul İşletme Enstitüsü: https://www.iienstitu.com/blog/sosyal-girisimcilik-nedir adresinden alınd 1

C1lga, İ. (2004). Bilim ve meslek olarak Türkiye'de sosyal hizmet. Ankara: Hacettepe Üniversitesi Sosyal Hizmetler Yüksekokulu.

Demirel, E. T. (2015). Sosyal Girişimcilik. E. Kaygın içinde, Girişimcilik: Temel kavramlar, Girişimcilik Türleri, Girişimcilikte Güncel Konular (s.111-129). İstanbul: Siyah İnci Akademi.

Demirel, E. T. (2017). Sosyal girişimcilik. Elâzığ: Fırat Üniversitesi İktisadi ve İdari Bilimler Fakültesi.

Denizalp, H. (2007). Toplumsal dönüşüm için sosyal girişimcilik rehberi. Ankara: STGM Yayınları.

Denizalp, H. (2009). Toplumsal Dönüşüm için sosyal girişimcilik rehberi. STGM.

Durmaz, F. (2015). Girişimcilik ders notları. Manisa: Manisa Celal Bayar Üniversitesi Turgutlu Meslek Yüksek Okulu. 
Duyan, V. (2014). Sosyal hizmet temelleri yaklaşımları müdahale yöntemleri. Ankara: Sosyal Çalışma Yayınları.

Düşünenlerin Düşüncesi. (2013, Haziran 29). Sosyal girişimcilik ve Türkiye'de durum. 05, 06, 2020 tarihinde Milliyet Web Sitesi. Adresinden alındı

Erbay, E. (2018). Güç Ve güçlendirme kavramları bağlamında sosyal hizmet uygulaması. Sosyal Politika Çalışmaları Dergisi, 19(42), 41-64.

Ersen, T. B., Kaya, D., ve Meydanoğlu, Z. (2010). Sosyal girişimler ve Türkiye ihtiyaç analizi raporu. İstanbul: TÜSEV Yayınları.

Günlü, E. (2015). Sosyal girişimclik olgusunun kavramsal analizi ve turizimde sosyal girişimcilik. Sosyal Ve Beşeri Bilimler Araştırmaları Dergisi, 16(35), 23-42.

Işık, V. (2015). Türkiye'deki Sosyal Girişim Yapılanması Analizi: ASHOKA Üyesi Sosyal Girişimler Üzerine Bir Alan Araştırması. Karatahta İş Yazlları Dergisi, 1(1), 63-76.

Kaya, Y. (2015, Şubat 19). Sosyal grişimcilik. 14.05.2020 tarihinde Prezi Web Sitesi: $\quad$ https://prezi.com/p5lnqz-se1vw/sosyal-girisimcilik/ adresinden alınd 1

Kırdaroğlu, N. (2015, Mart 30). Sosyal girişimcilik. 14.05.2020 tarihinde Prezi Web Sitesi: https://prezi.com/btrwyr26bgkl/sosyal-girisimcilik/ adresinden alındı

Koç, S. Ç. (2015). Sosyal Hizmet uzmanlarının sorun çözme becerileri üzerine bir araştırma. Ankara: Hacettepe Üniversitesi Sosyal Bilimler Enstitüsü Sosyal Hizmet Anabilim Dalı.

Kongar, E. (1972). Sosyal Çalışma'ya giriş. Ankara: Sosyal Bilimler Derneği Yayınları.

Kümbül, G. B. (2011). Yoksullukla mücadelede sosyal girişimcilik: Ashoka üyelerinden sosyal yenilikçi örnek uygulamalar. Dokuz Eylül Üniversitesi Sosyal Bilimler Enstitüsü Dergisi, 13(3), 79-111.

Martin, R. L., ve Osberg, S. (2007). Social Entrepreneurship: The Case for definition. Kaliforniya: Leland Stanford Jr. University.

Meydanoğlu, Z. (2018, Temmuz 9). Sosyal girişimcilik nedir? Sosyal girişimci kimdir? Medium Şirket Sitesi: https://medium.com/@AshokaTurkiye/sosyal-giri\%C5\%9Fimciliknedir-sosyal-giri\%C5\%9Fimci-kimdir-3c0448e00271 adresinden alındı 
Özdevecioğlu, M., ve Çingöz, A. (2009). Sosyal girişimcilik ve sosyal girişimciler: Teorik çerçeve. Erciyes Üniversitesi İktisadi ve İdari Bilimler Fakültesi Dergisi, 32, 81-95.

Özeren, E., Saatçioğlu, Ö.Y. (2016). Sosyal girişimcilikte inovasyon ve farklılıkları yönetmek: Çöp(m)adam örneği. Girişimcilik ve İnovasyon Yönetimi Dergisi, 5(1), 71-96

Sarı, E. (2018, Aralık 22). Sosyal girişimcilik toplumsal refahı artırır. 08.05.2020 tarihinde Ticari Hayat Web Sitesi: http://www.ticarihayat.com.tr/haber/Sosyal-girisimcilik-toplumsalrefahi-arttirir/28351 adresinden alınd 1

Sheafor, B. W., ve Horejsi, C. J. (2015). Sosyal hizmet uygulaması temel teknikler ve ilkeler. Ankara: Nika Yayınevi.

Şeker, A. (2015). 101 soruda sosyal çalışma ve sosyal hizmetler. Ankara: SABEV Yayınları.

Şimşek, G., ve Altun, F. (2020). Sosyal belediyecilikte sosyal hizmetlerin ve sosyal girişimci faaliyetlerin rolü. Sosyal Çalışma Dergisi, 4(1), 55-61.

Taş, H. Y., ve Menteşe, B. (2016). Sosyal Girişimciliğin Gelişimi: "Avrupa Birliği ülkelerinde ve Türkiye'de sosyal girişimciliğin boyutları". 2. ULUSLARARASI ÇIN'DEN ADRIYATIK'E SOSYAL BiLIMLER KONGRESi (s. 305-320). Hatay: İKSAD; Payas Belediyesi.

Taş, H. Y., ve Şemşek, İ. (2017). Türkiye ve dünyadan sosyal grişimcilik örnekleri ve istihdama katkıları. HAK-ISS Uluslararası Emek ve Toplum Dergisi, 6(6), 480-497.

Thompsan, N. (2014). Kuram ve uygulamada sosyal hizmeti anlamak. Ankara: Dipnot Yayınları.

Truell, R. (2014, Ağustos 7). Sosyal hizmet nedir? 06.05.2020 tarihinde IFSW: https://www.ifsw.org/sosyal-hizmet-nedir/ adresinden alınd 1

Yalçın, S. M., (2018). Türkiye'de sosyal girişimcilik Koç Üniversitesi öğrencilerinin gözünden. İstanbul: Koç Üniversitesi Yayını

Yumuşakipek, H. D. (2015). Aile işletmelerinde iç girişimciliğin sosyal girişimciliğe etkisi: Afyonkarahisar'da bir araştırma. Afyonkarahisar: T.C. Afyon Kocatepe Üniversitesi Sosyal Bilimler Enstitüsü İşletme Ana bilim Dalı Yönetim ve Organizasyon Bilim Dalı Yüksek Lisans Tezi.

Zastrow, C. (2014). Sosyal hizmete giriş. Ankara: Nika Yayınevi. 


\section{Kaynakça Bilgisi / Citation Information}

Apaydın, E. ve Altun, F. (2021). Sosyal girişimcilik ile sosyal hizmet arasındaki ilişkinin değerlendirilmesi. OPUS-Uluslararası Toplum Araştırmaları Dergisi, 18(39), 777-803. DOI: 10.26466/opus.841939. 